DOI: $10.52362 /$ jmijayakarta.v1i1.414

\title{
Perancangan sistem informasi pelayanan penduduk berbasis website di rw 010 Kelurahan Keagungan Kecamatan Tamansari - Jakarta Barat
}

\author{
Putri Setiani $^{1}$, Ifan Junaedi ${ }^{2}$, Anton Zulkarnain Sianipar ${ }^{3}$ Verdi Yasin $^{4}$ \\ Program Studi Sistem Informasi, STMIK Jayakarta ${ }^{1}$, Program Studi Teknik Informatika, STMIK Jayakarta ${ }^{2}$ \\ Program Studi Teknik Informatika, STMIK Jayakarta ${ }^{3}$, Program Studi Teknik Informatika, STMIK Jayakarta ${ }^{4}$ \\ putrisetiani47@gmail.com¹, ifanjunaedi8@gmail.com², antonz.jayakarta@gmail.com³ \\ ,verdiyasin29@gmail.com ${ }^{4}$
}

\begin{abstract}
ABSTRAK
Proses pengolahan data penduduk serta pembuatan surat yang berjalan saat ini, terdapat beberapa kendala yang terindentifikasi yakni kesulitan dalam mencari data karna masih tersimpan pada buku kependudukan penduduk dan membutuhkan waktu yang lama dalam mengajukan surat. Tujuan penelitian yaitu merancang serta membangun suatu Sistem Informasi Pelayanan Penduduk secara online. Manfaat yang diperoleh dari penelitian ini ialah sistem dapat memudahkan proses pelayanan antar penduduk dan pengurus dalam pendataan penduduk serta permohonan dan pembuatan surat. Dalam membangun suatu sistem menggunakan metode pengembangan sistem SDLC dengan model Waterfall, untuk pemodelan sistem menggunakan UML (Unified Modeling Language) serta perangkat lunak yang digunakan dalam membangun sistem ini memakai bahasa pemograman PHP (Hypertext Preprocessor) serta XAMPP sebagai koneksi kedalam database yaitu MySQL. Metode pengumpulan data yang digunakan menggunakan metode observasi, wawancara dan kepustakaan. Hasil dari penelitian ini menunjukkan jika penggunaan sistem informasi pelayanan penduduk secara online dapat membantu mempermudah pendataan penduduk dalam pengolahan data penduduk dan dalam pembuatan surat serta mengesahkan surat.
\end{abstract}

Kata kunci: Sistem Informasi, Waterfall, UML.

\begin{abstract}
The process of processing population data and making letters that are currently running, there are several identified obstacles, namely the difficulty in finding data because it is still stored in the population population book and requires a long time to submit a letter. The research objective is to design and build an online Citizen Service Information System. The benefit obtained from this research is that the system can facilitate the process of service between residents and administrators in population data collection and application and writing of letters. In building a system using the SDLC system development method with the Waterfall model, for system modeling using UML (Unified Modeling Language) and the software used in building this system using the PHP (Hypertext Preprocessor) programming language and XAMPP as a connection to the database, namely MySQL. Data collection methods used are observation, interview and literature methods. The results of this study indicate that the use of an online population service information system can help facilitate population data collection in population data processing and in making letters and validating letters.
\end{abstract}

Keywords: Information system, Waterfall, UML.

\section{PENDAhuluan}

Perkembangan ilmu pengetahuan dan teknologi saat ini semakin cepat dan mudah diakses, menjadikan kita untuk lebih membuka diri dalam menerima perubahan - perubahan yang terjadi akibat kemajuan dan perkembangan tersebut. Didalam majunya perkembangan teknologi membuat penyebaran informasi tidak hanya melalui media offline melainkan media online pun turut memberikan kontribusinya dalam penyampaian informasi yang ada bagi suatu organisasi atau perusahaan yang membutuhkan suatu sistem yang cepat, tepat dan akurat. Untuk menunjang produktifitas, efektifitas dan efisiensi dalam suatu organisasi dalam menyelesaikan masalah manajemen, terutama dalam memberikan pelayanan. Seperti pelayanan kepada penduduk di RT/RW. RT/RW mempunyai peranan penting pada pemeliharaan dan pelestarian nilai-nilai kehidupan masyarakat yang

Ciptaan disebarluaskan di bawah Lisensi Creative Commons Atribusi 4.0 Internasional. http://journal.stmikjayakarta.ac.id/index.php/JMIJayakarta 
DOI: $10.52362 / j m i j a y a k a r t a . v 1 i 1.414$

berdasarkan sebuah kekeluargaan dan gotong-royong, meningkatkan kelancaran dalam melaksanakan tugas pemerintah desa ataupun kelurahan pada pembangunan dan kemasyarakatan dan memberdayakan seluruh usaha meningkatkan kesejahteraan masyarakat [1].

Pelayanan di RW 010 terutama pada proses pengolahan informasi data dalam pelayanan antara penduduk dan pengurus belum adanya sistem komputerisasi yang terintegrasi. Untuk pendataan penduduk dilakukan tiap pengurus RT di RW 010 Kelurahan Keagungan dengan mencatat data penduduk satu - persatu dalam buku kependuduk. Dalam hal tersebut terdapat kendala terutama berkaitan dengan waktu karena membutuhkan waktu yang terbilang lama dan belum lagi data yang tercatat sering hilang atau rusak karena penyimpanan arsip data yang masih menggunakan media kertas. Serta dalam proses pengajuan pembuatan surat, penduduk harus menemui pihak pengurus terlebih dahulu untuk mengajukan dan mendapatkan surat tersebut. Ini terkadang tidak sedikit membuat penduduk menjadi mengeluh karena pada saat menemui pengurus ternyata pengurus tersebut sedang tidak ada ditempat.

Dari permasalahan yang terjadi dan dengan adanya perkembangan teknologi, maka di RW 010 Kelurahan Keagungan perlu dibuat suatu sistem terkomputerisasi yang terintegrasi dan secara online. Agar data yang tersimpan lebih aman dan lebih mempermudah dalam proses pelayanan antar penduduk dan pengurus.

\section{METODE DAN MATERI}

\subsection{Materi}

Sistem

Secara umum pengertian sistem yaitu sekumpulan objek, unsur - unsur atau bagian - bagian yang mempunyai arti berbeda - beda yang saling berhubungan, saling bekerjasama serta saling mempengaruhi satu sama lain dan memiliki keterkaitan pada sebuah rencana yang sama dalam mencapai suatu tujuan tertentu pada lingkungan yang kompleks. (Bitar, 2021) [2]

Sedangkan definisi lainnya sistem pada dasarnya adalah sekelompok unsur yang erat berhubungan satu dengan lainnya, yang berfungsi bersamaan untuk mencapai tujuan tertentu.

Beberapa elemen yang dapat membentuk sebuah sistem, yaitu :

a) Tujuan

Setiap sistem mempunyai tujuan (goal), entah hanya satu atau mungkin lebih. Tujuan inilah yang menjadi pemotivasi yang dapat mengarahkan sistem. Tanpa adanya tujuan, sistem tidak akan terarah dan tidak terkendali.

b) Masukan

Masukan (input) sistem merupakan segala sesuatu yang masuk ke dalam sistem dan selajutnya akan menjadi bahan yang dapat diproses. Masukan dapat berupa sesuatu yang nampak (secara fisik) ataupun yang tidak nampak.

c) Proses

Proses adalah bagian yang melakukan sebuah perubahan atau transformasi dari masukan menjadi keluaran yang bermanfaat dan lebih bernilai, misalnya berupa informasi atuapun produk, tetapi juga dapat berupa sesuatu yang tidak berguna.

d) Keluaran

Keluaran (output) merupakan hasil dari pemrosesan. Pada sistem informasi, keluaran bisa berupa suatu informasi, saran, cetak laporan, dan sebagainya.

e) Batas

Yang disebut batas (boundary) sistem adalah pemisah antara sistem dan daerah di luar sistem (lingkungan). Batas sistem menentukan konfigurasi, ruang lingkup, atau kemampuan sistem.

f) Mekanisme pengendalian dan umpan balik

Mekanisme pengendalian (control mechanism) diwujudkan dengan menggunakan umpan balik (feedback), yang mencuplik keluaran. Umpan balik ini digunakan untuk mengendalikan baik masukan maupun proses. Tujuannya untuk mengatur agar sistem berjalan sesuai dengan tujuan.

g) Lingkungan

Lingkungan adalah segala sesuatu yang berada di luar sistem. Lingkungan bisa berpengaruh terhadap operasi sistem dalam arti bisa merugikan atau menguntungkan sistem itu sendiri.

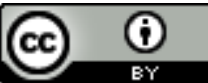


Pelayanan

DOI: 10.52362/jmijayakarta.v1i1.414

(Furqoni, 2014) Pelayanan pada hakikatnya merupakan serangkaian aktivitas, karna itu proses pelayanan berlangsung secara teratur dan berkesinambungan meliputi seluruh kehidupan organisasi dalam penduduk. Proses yang dimaksudkan dilakukan sehubungan dengan saling memenuhi kebutuhan antara penerima serta pemberi pelayanan. [3]

Definisi pelayanan merupakan kegiatan yang dapat ditawarkan oleh suatu pihak kepada pihak lain, yang pada umumnya tidak berwujud dan tidak mengakibatkan kepemilikan apapun.

Penduduk

(Asmuruf, Rumate, \& Kawung, 2015) Definisi pelayanan merupakan kegiatan yang dapat ditawarkan oleh suatu pihak kepada pihak lain, yang pada umumnya tidak berwujud dan tidak mengakibatkan kepemilikan apapun. [4]

Basis Data

[5] (Swara \& Pebriadi, 2016) Basis data atau database adalah kumpulan informasi yang disusun dan merupakan suatu kesatuan yang utuh yang disimpan didalam perangkat keras (computer) secara sistematis sehingga dapat diolah menggunakan perangkat lunak. Dengan sistem tersebut data yang terhimpun dalam suatu database dapat menghasilkan informasi yang berguna.

\subsection{Metode}

Pada penelitian ini mengacu pada Sistem Development Life Cycle (SDLC) dengan model waterfall. Model ini merupakan sebuah pendekatan terhadap pengembangan perangkat lunak yang secara sistematik dengan beberapa tahapan didalamnya yaitu analisis, perancangan dan implementasi [6]. Pada tahap analisis dilakukan pengumpulan data dengan obyek penelitian yaitu dengan melakukan wawancara dengan pengurus RT maupun RW di RW 010 untuk mengetahui sistem yang sedang berjalan dan dilakukan pengumpulan data terkait dengan proses pelayanan seperti prosedur pendataan penduduk, pengajuan surat dan lain - lain.

Berdasarkan hasil dari pengumpulan data dapat ditetapkan lingkup permasalahannya yaitu menitikberatkan pada kinerja pengurus dalam menjalankan tugasnya untuk melayani penduduknya dan komunikasi antar keduanya terkait dalam pendataan, pengajuan serta pembuatan surat.

Hasil pengumpulan data kemudian akan diolah untuk dilakukan analisis dalam menentukan permasalahan yang terjadi beserta dampaknya agar dapat diketahui apa saja yang dibutuhkan untuk mengatasi masalah yang terjadi. Hasil dari analisis akan dijadikan acuan dalam melakukan perancangan sistem yang nantinya diharapkan dapat mengatasi permasalahan yang terjadi. Pada tahapan terakhir, desain yang telah dibuat akan di implementasikan.

\section{PEMBahaSa DAN HASIL}

3.1. Analisis dan Perancangan

1. Gambaran Umum Sistem yang Berjalan

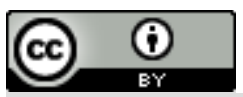


DOI: $10.52362 / j m i j a y a k a r t a . v 1 i 1.414$

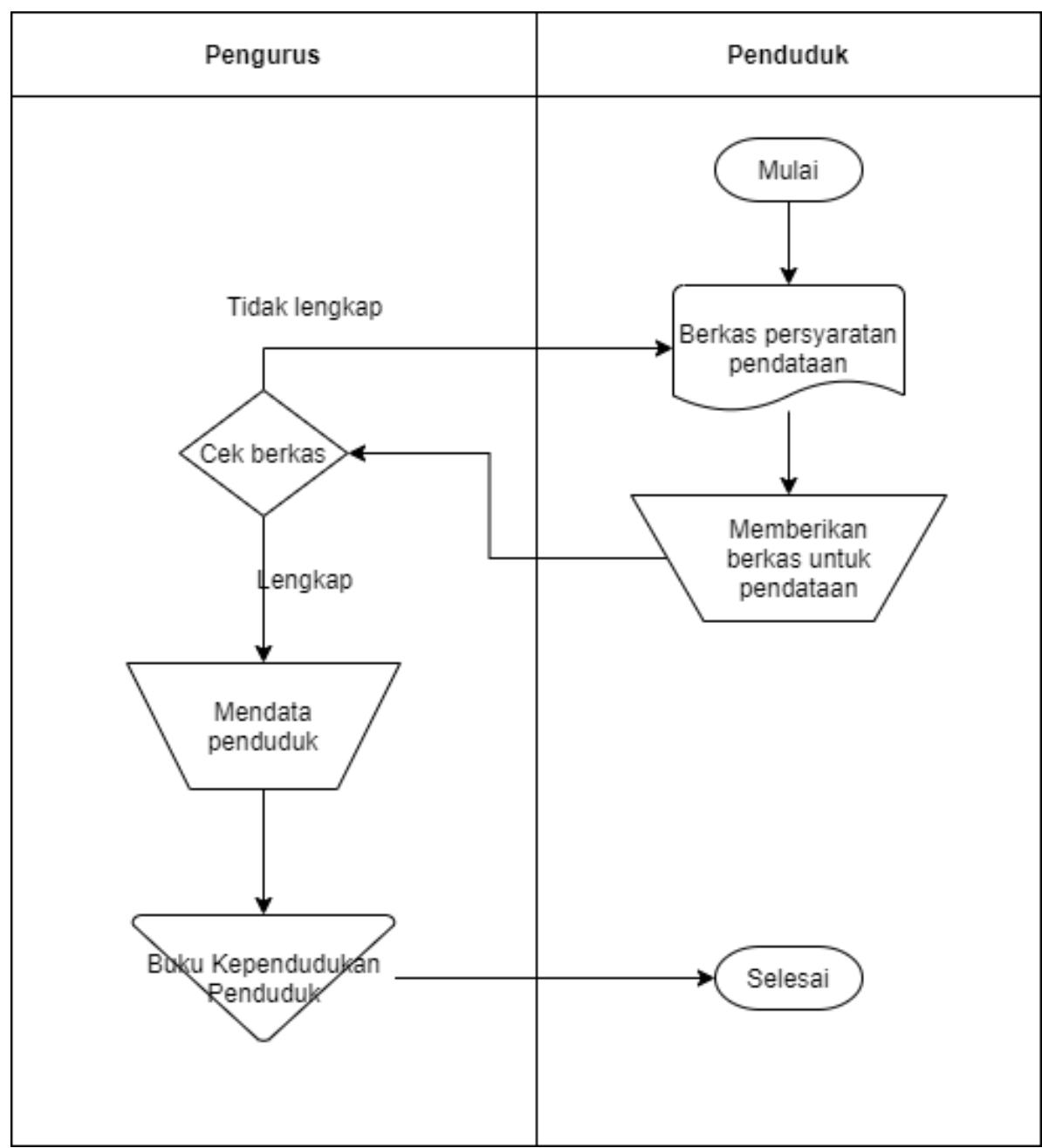

Gambar 1. Flowchart Pendataan Penduduk Manual

Berdasarkan observasi yang dilakukan di RW 010 Kelurahan Keagungan. Proses sistem yang berjalan berkaitan dengan pelayanan penduduk dalam pendataan. Dimana pengurus RT mendatangi rumah penduduk untuk mendata penduduk disekitar lingkungannya. Setelah mendatangi penduduk, pengurus RT akan meminta berkas berupa KTP atau KK sebagai syarat untuk pendataan jika sudah sesuai dengan ketentuan kemudian pengurus akan mendatanya.

Dalam proses ini pengurus Ketua/Wakil RT harus mendatangi penduduk jika ingin mendata dan data akan dicatat dalam buku kependudukan penduduk. Kendalanya yaitu dalam pendataan masih manual dicatat satu - persatu. Selain itu dibutuhkan waktu yang lebih dalam pendataan dan data rawan hilang. 
DOI: $10.52362 / j m i j a y a k a r t a . v 1 i 1.414$

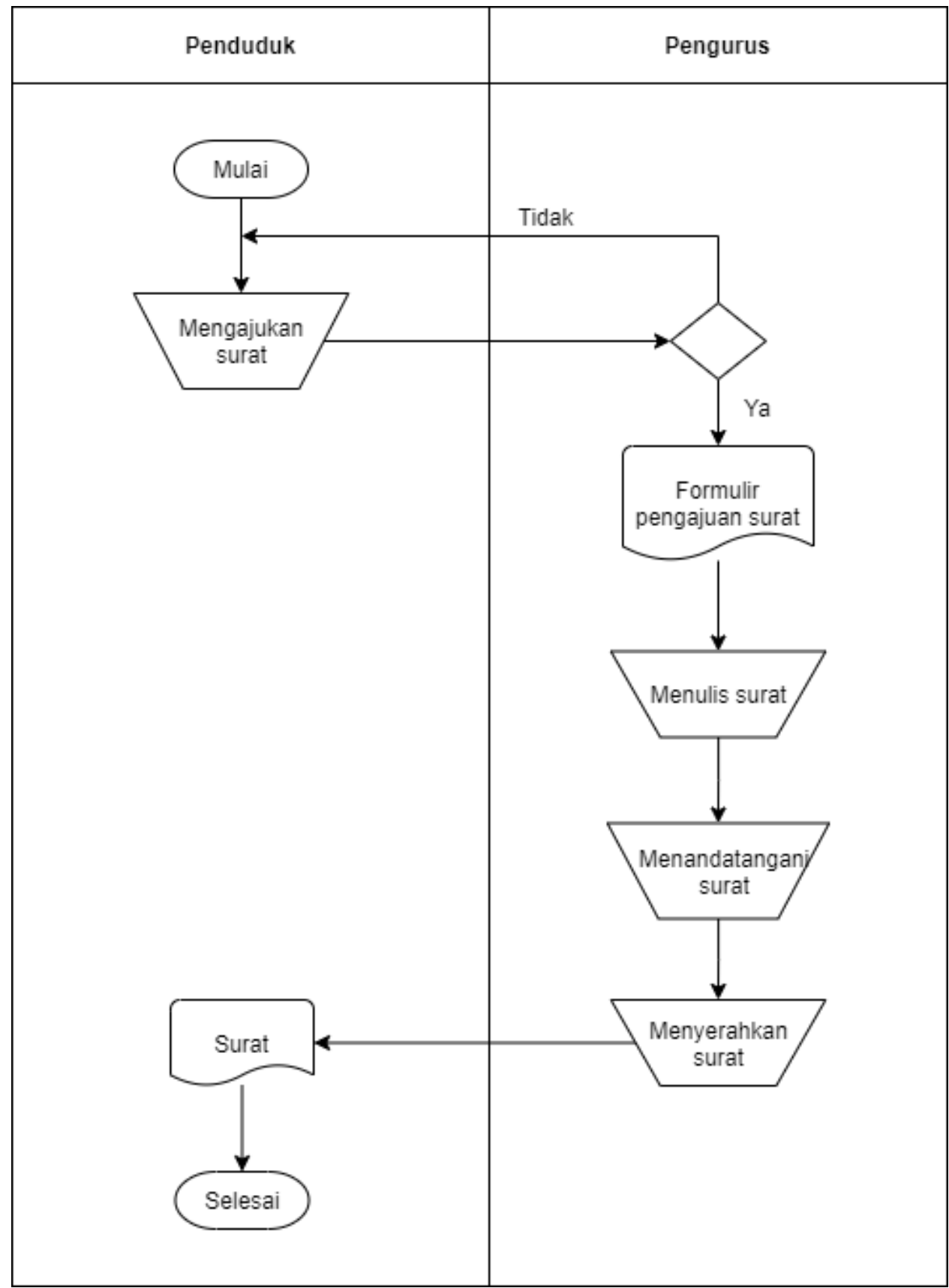

Gambar 2. Flowchart Pengajuan Surat

Dalam pengajuan surat, penduduk datang langsung ke ketua RT untuk meminta surat keterangan/pengantar dari RT. Jika surat sudah diterima kemudian penduduk mendatangi ketua RW untuk meminta surat agar di acc oleh RW dalam bentuk tanda tangan serta stempel.

Dalam proses ini penduduk harus mendatangi Ketua RT dan Ketua RW jika ingin mengajukan surat. Kendalanya yaitu Ketua RT atau RW tidak selalu berada di tempat karena mempunyai kewajiban pekerjaan lain. Selain itu dibutuhkan waktu dan tenaga lebih untuk mengajukan surat.

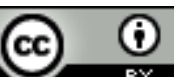

Ciptaan disebarluaskan di bawah Lisensi Creative Commons Atribusi 4.0 Internasional. http://journal.stmikjayakarta.ac.id/index.php/JMIJayakarta 
DOI: $10.52362 / j m i j a y a k a r t a . v 1 i 1.414$

2. Gambaran Umum Sistem yang Diusulkan

Use Case Diagram

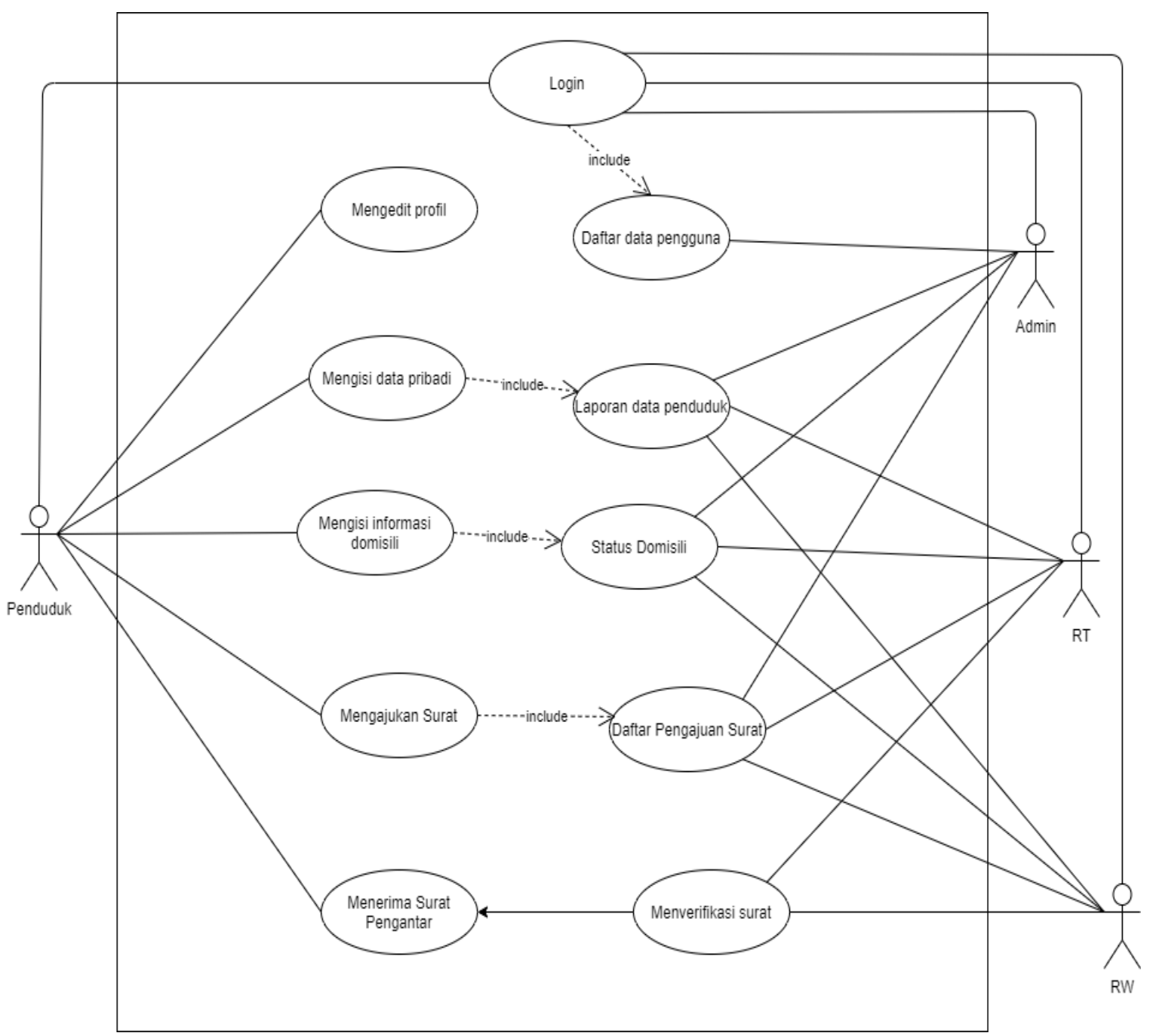

Gambar 3. Use Case Diagram Sistem Usulan

Berdasarkan use case diatas dapat dijelaskan mengenai sistem. Sebelum penduduk, RT, RW dan admin memasuki halaman dashboard harus terlebih dahulu melakukan login. Untuk penduduk dapat diarahkan untuk wajib mengisi data pribadi, mengisi informasi mengenai domisili dan dapat pula mengajukan surat jika ingin mengajukan.Data pengguna, data penduduk serta data domisili yang telah tersimpan dapat dikelola oleh admin. Admin mengelola sepenuhnya dari sistem tersebut. Sedangkan RT atau RW akan mengelola laporan data penduduk, data domisili serta daftar ajuan surat. pengajuan surat yang telah terkirim akan sampai kepada RT ataupun RW untuk diverifikasi. Setelah terverifikasi hasil surat akan terkirim kembali kepada penduduk. 
DOI: $10.52362 / j m i j a y a k a r t a . v 1 i 1.414$

Squence Diagram

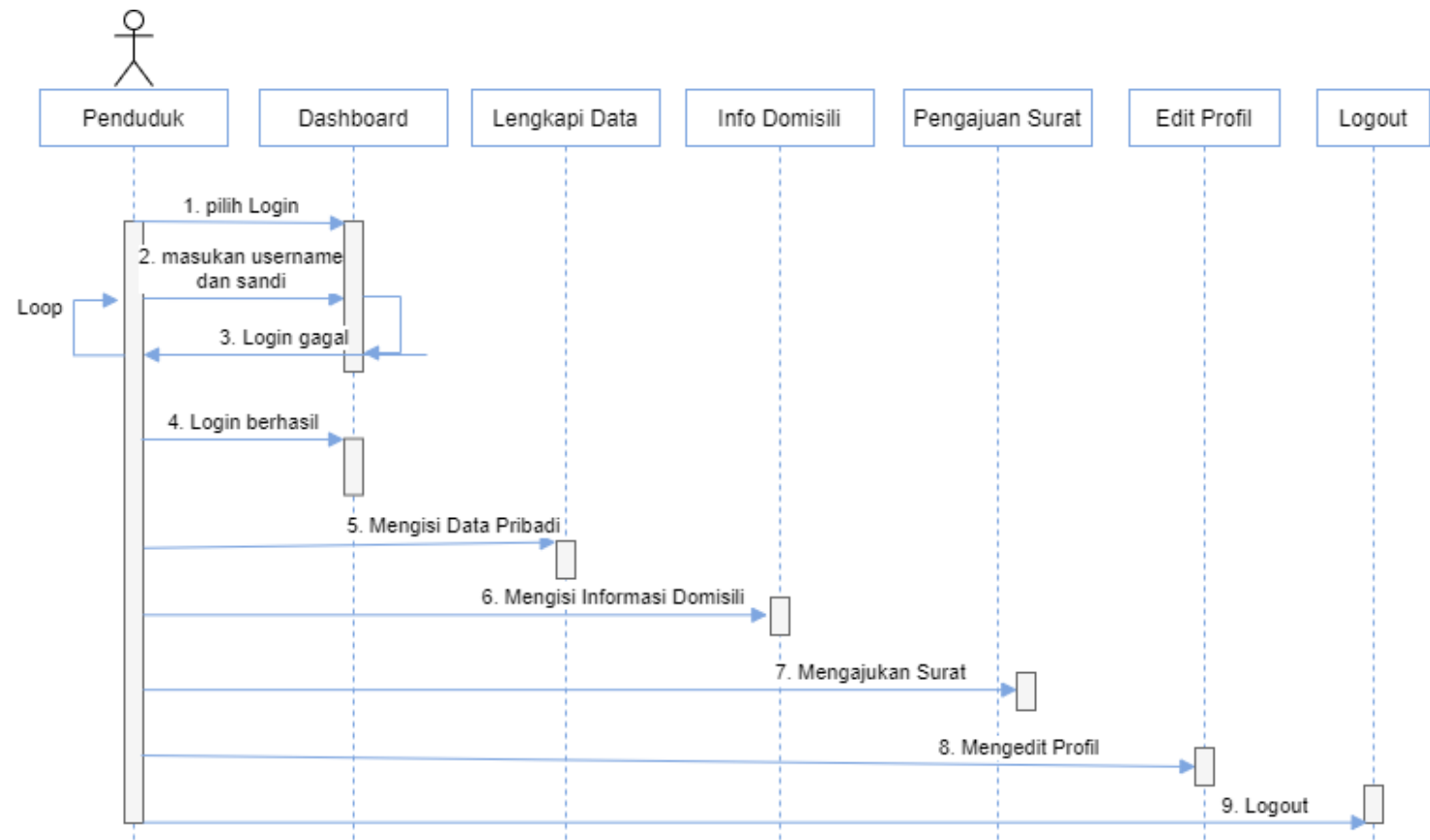

Gambar 4. Squence Diagram Penduduk

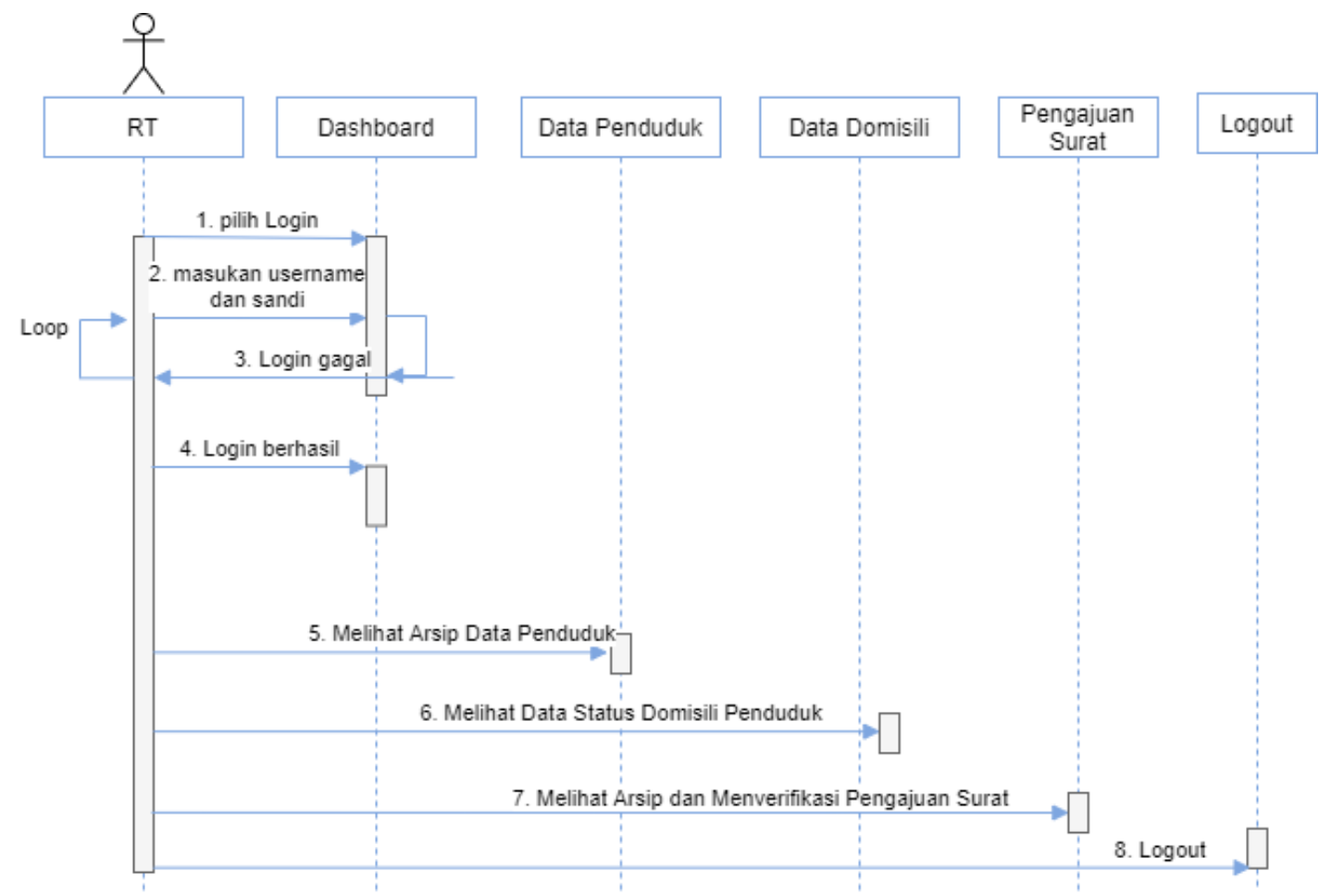

Gambar 5. Squence Diagram RT 
DOI: $10.52362 / j m i j a y a k a r t a . v 1 i 1.414$

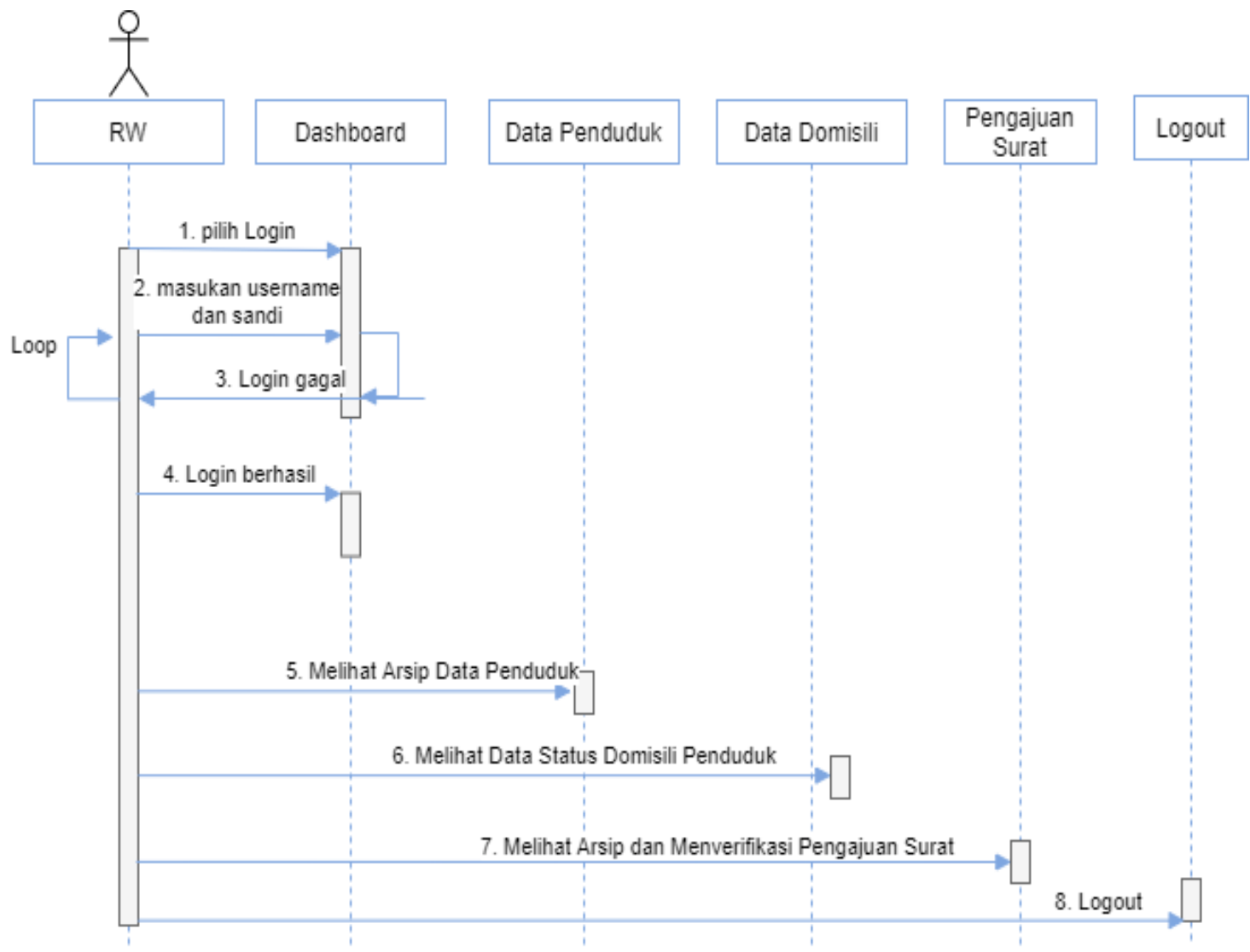

Gambar 6. Squence Diagram RW

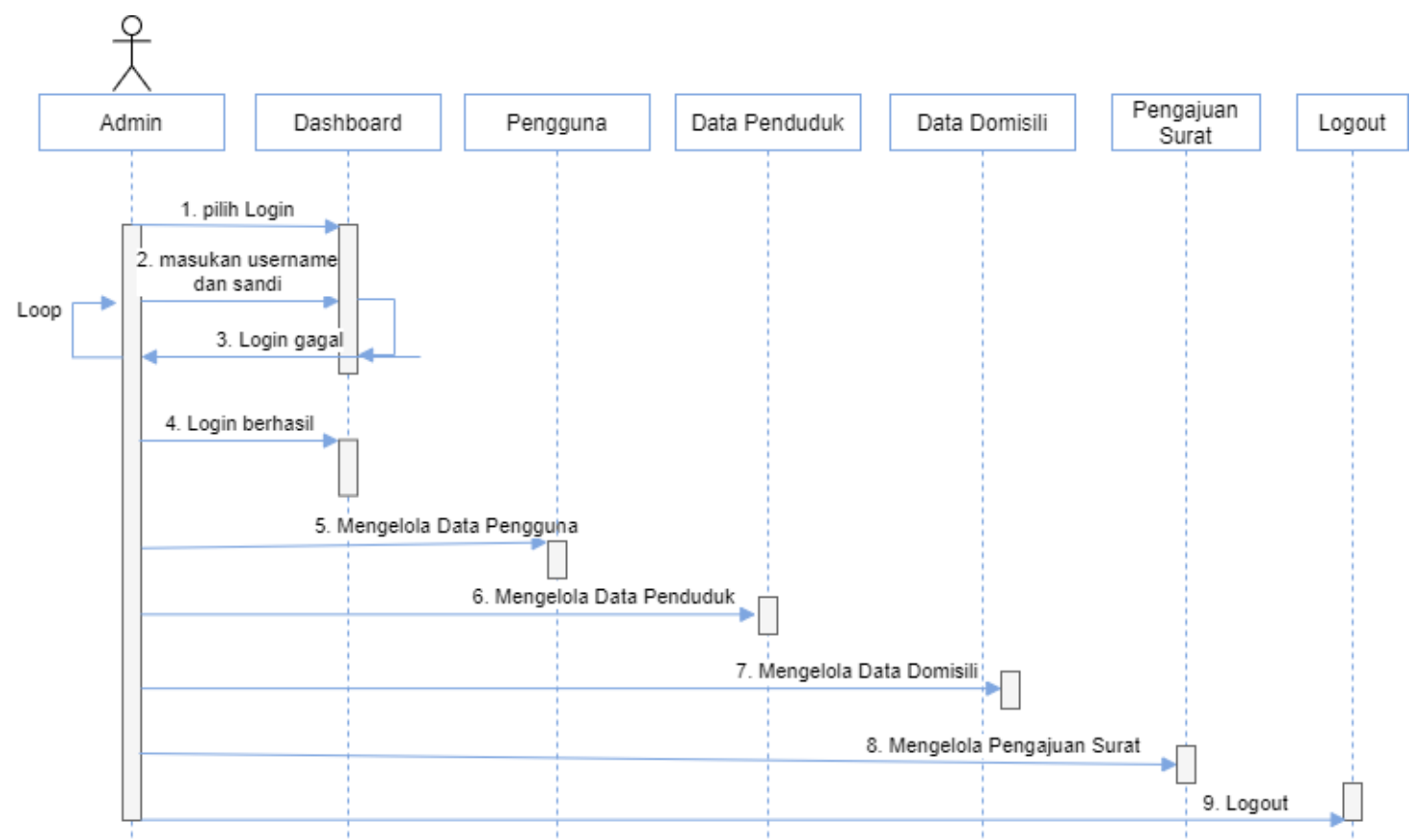

Gambar 7. Squence Diagram Admin 
DOI: $10.52362 / j m i j a y a k a r t a . v 1 i 1.414$

\section{Class Diagram}

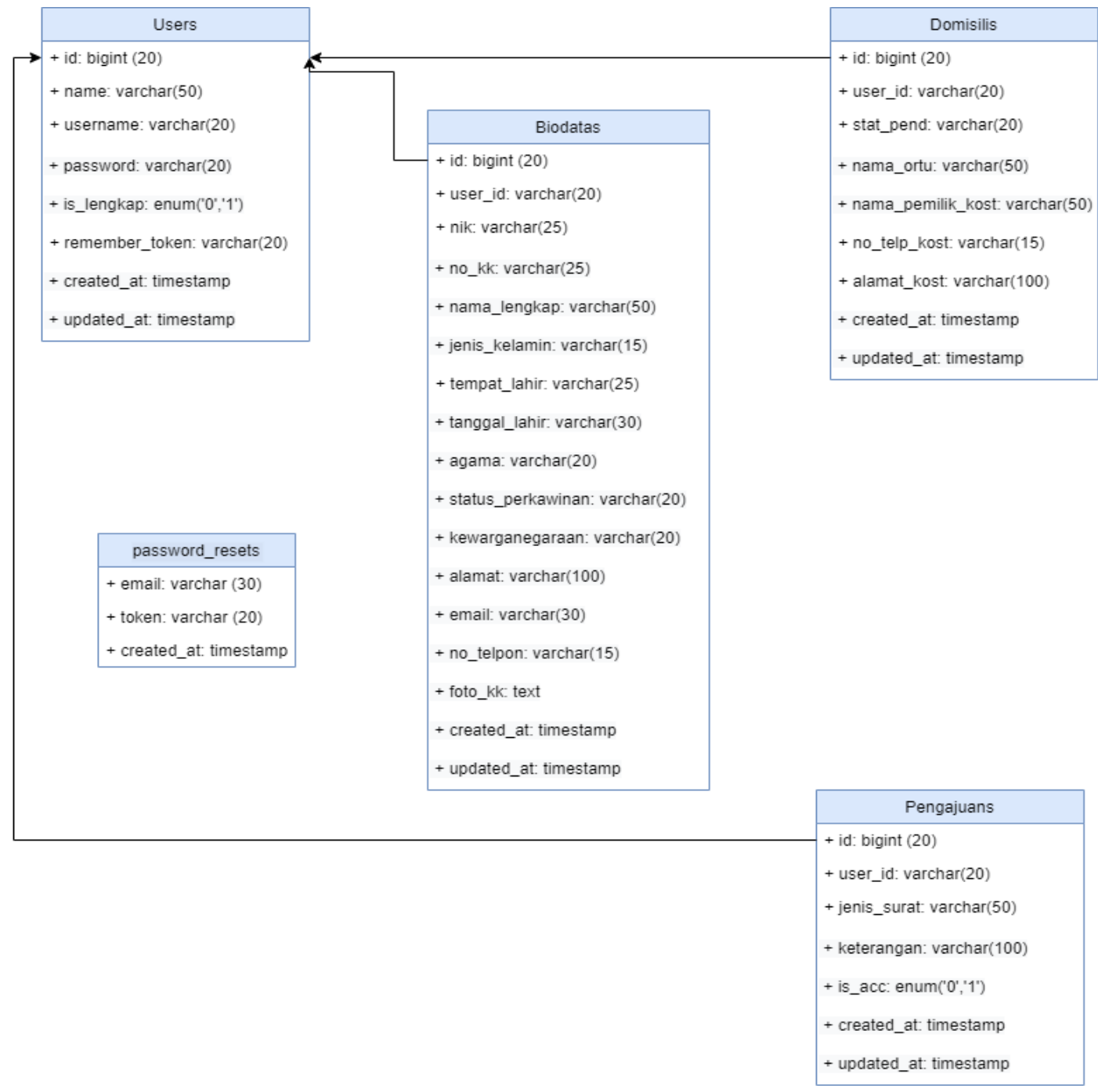

Gambar 8. Class Diagram

3.2. Implementasi

Berikut adalah hasil implementasi dari perancangan yang telah dibuat :

1. Halaman Login 
DOI: $10.52362 /$ jmijayakarta.v1i1.414

\section{Pelayanan Penduduk RW 010}

\section{R Username}

A Sandi

$\square$ Ingat Saya

Gambar 9. Implementasi Antarmuka Login

2. Malallanl utalla (Derallua)

\section{Menciptakan Pelayanan}

yang Baik, Cepat, Tepat dan Akurat bagi Penduduk

di Lingkungan RW 010

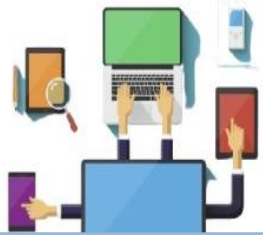

Gambar 10. Implementasi Halaman Utama

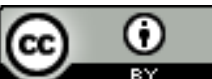

Ciptaan disebarluaskan di bawah Lisensi Creative Commons Atribusi 4.0 Internasional. http://journal.stmikjayakarta.ac.id/index.php/JMIJayakarta 
DOI: $10.52362 / j m i j a y a k a r t a . v 1 i 1.414$

3. Halaman Dashboard Penduduk

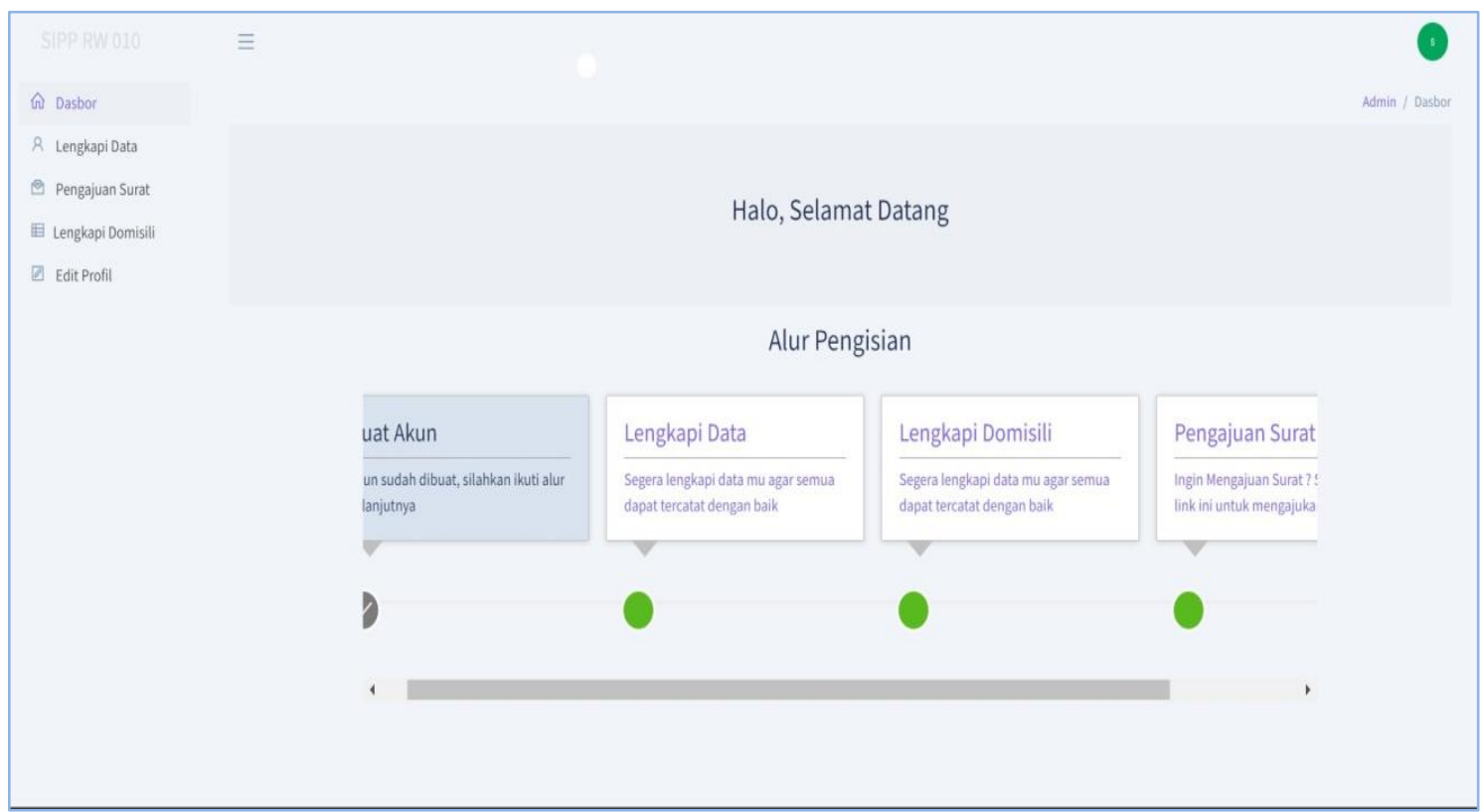

Gambar 11. Implementasi Halaman Dashboard Penduduk

4. Halaman Pengisian Data

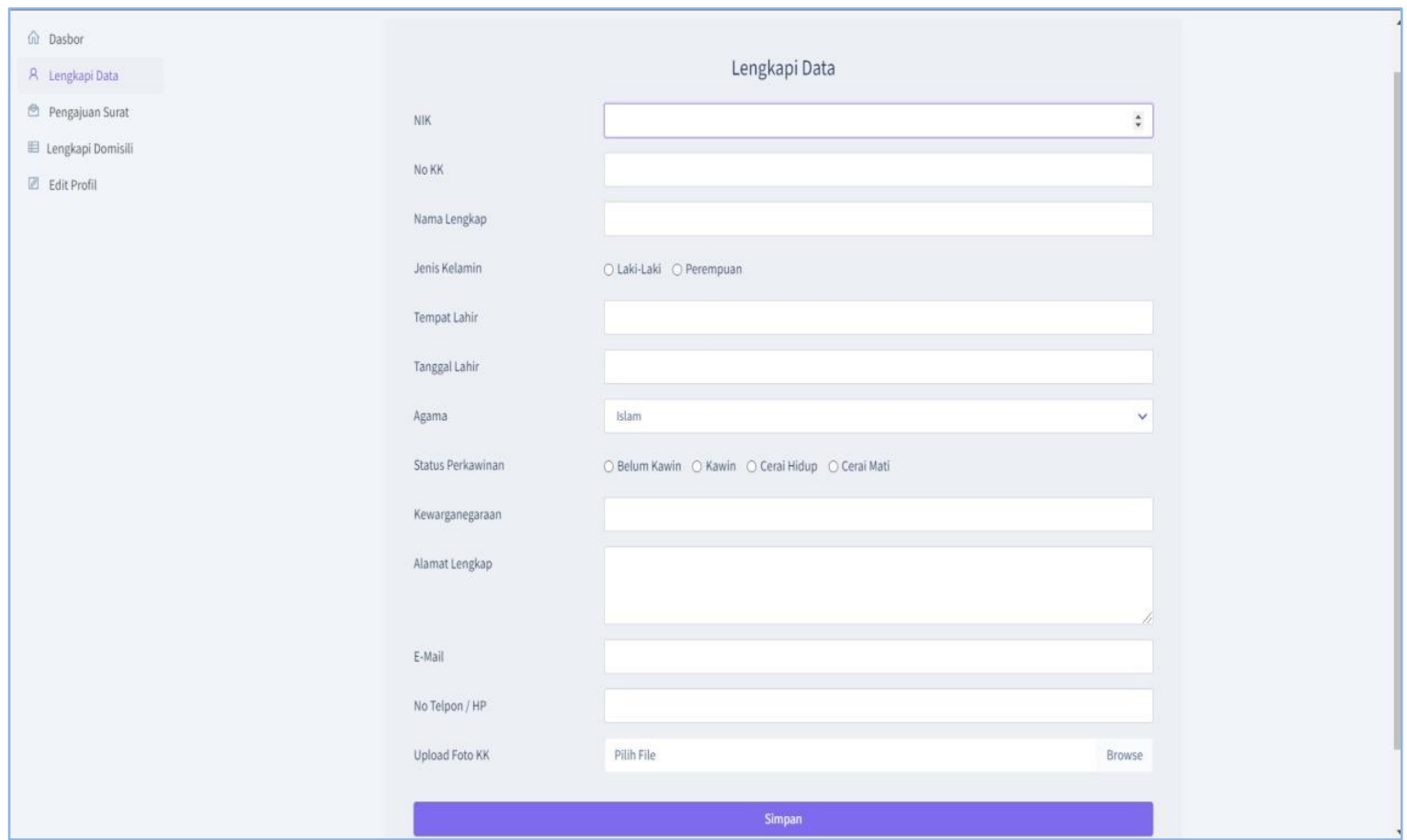

Gambar 12. Implementasi Halaman Pengisian Data

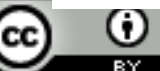

Ciptaan disebarluaskan di bawah Lisensi Creative Commons Atribusi 4.0 Internasional. http://journal.stmikjayakarta.ac.id/index.php/JMIJayakarta 
DOI: $10.52362 / j m i j a y a k a r t a . v 1 i 1.414$

5. Halaman Lengkapi Domisili

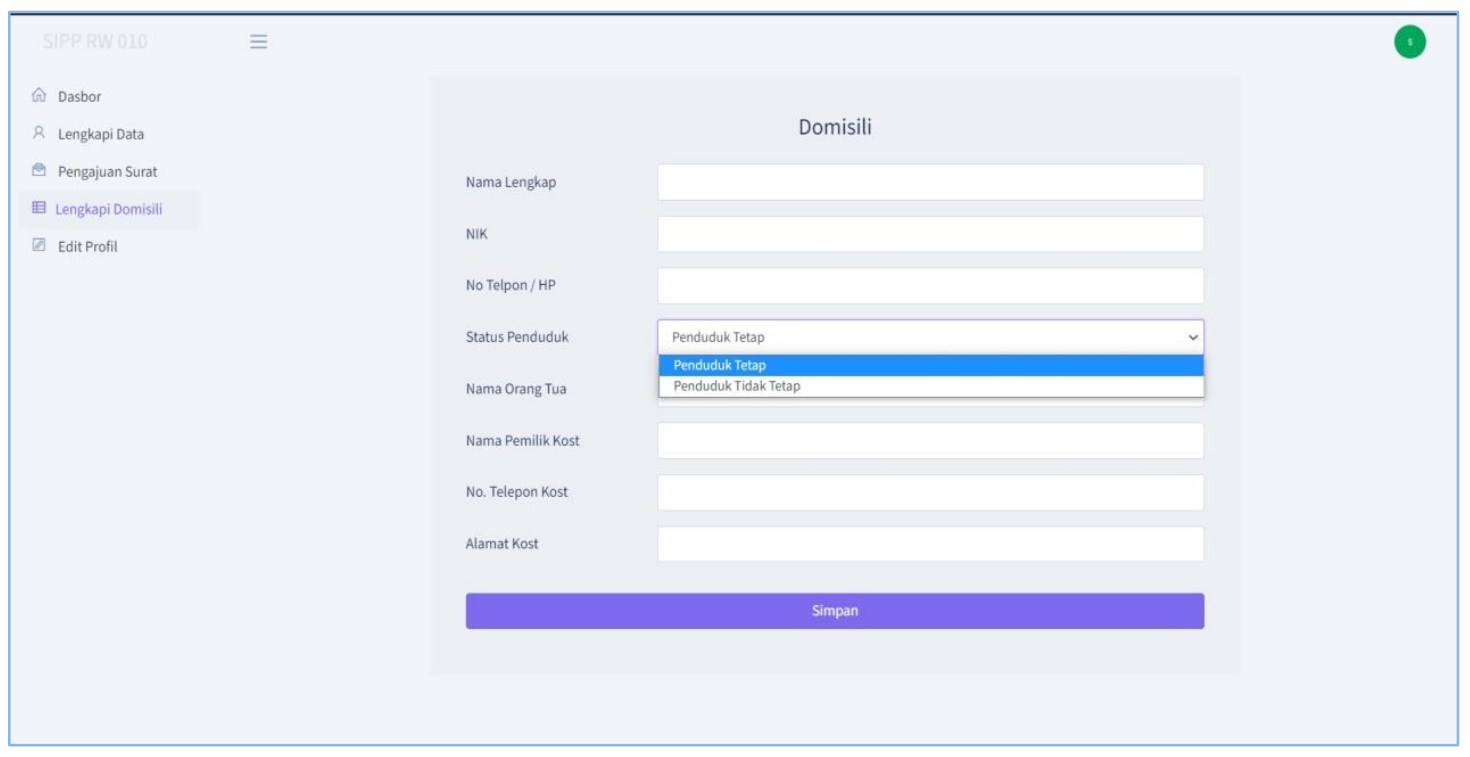

Gambar 13. Implementasi Halaman Pengisisan Informasi Domisili

6. Halaman Pengajuan Surat

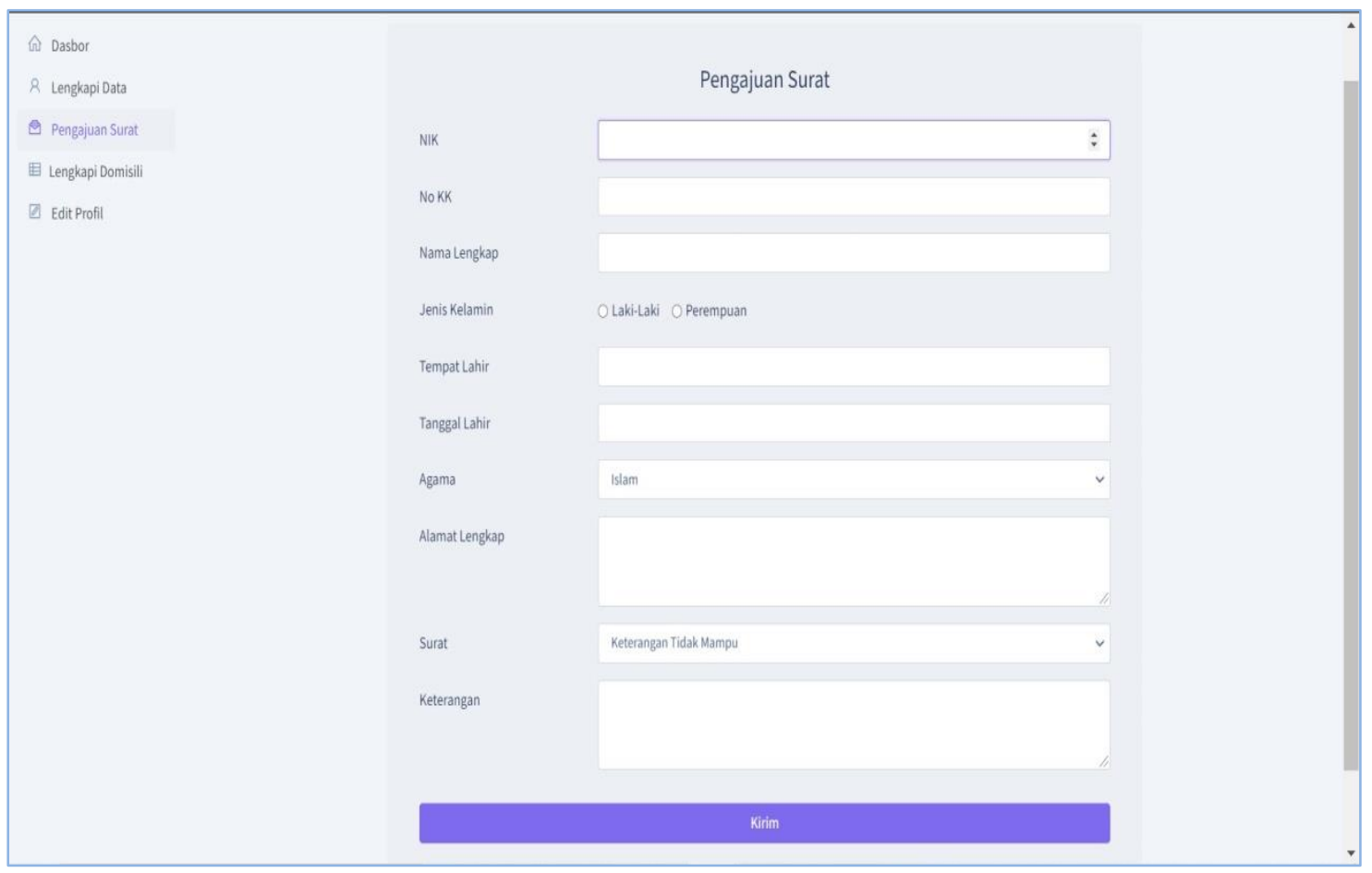

Gambar 14. Implementasi Halaman Pengajuan Surat

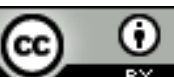

Ciptaan disebarluaskan di bawah Lisensi Creative Commons Atribusi 4.0 Internasional. http://journal.stmikjayakarta.ac.id/index.php/JMIJayakarta 
DOI: $10.52362 / j m i j a y a k a r t a . v 1 i 1.414$

7. Halaman Dashboard Admin

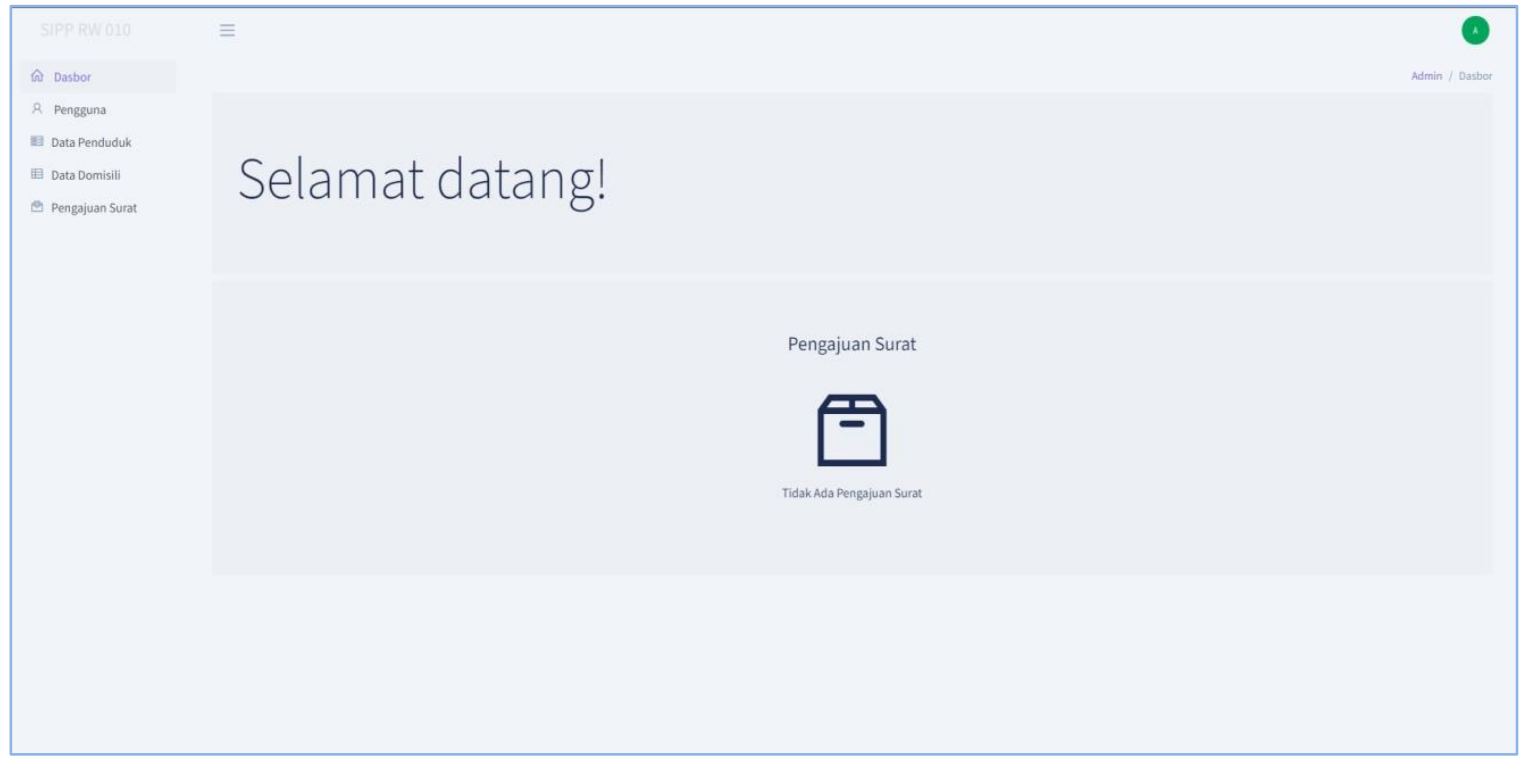

Gambar 15. Implementasi Halaman Admin

8. Halaman Data Penduduk

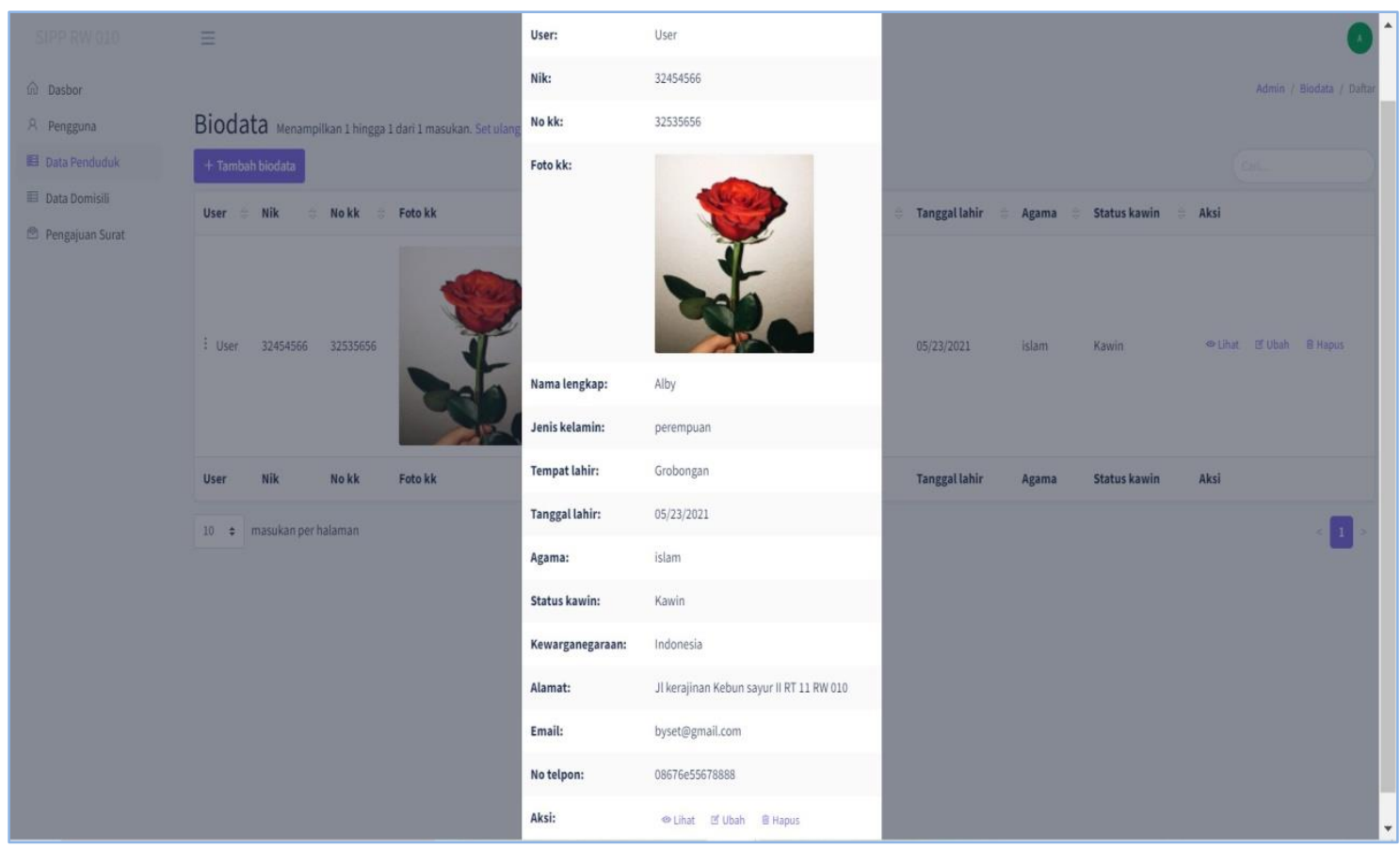

Gambar 16. Implementasi Halaman Data Penduduk

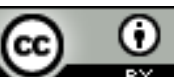

Ciptaan disebarluaskan di bawah Lisensi Creative Commons Atribusi 4.0 Internasional. http://journal.stmikjayakarta.ac.id/index.php/JMIJayakarta 
DOI: 10.52362/jmijayakarta.v1i1.414

9. Halaman Data Domisili Penduduk

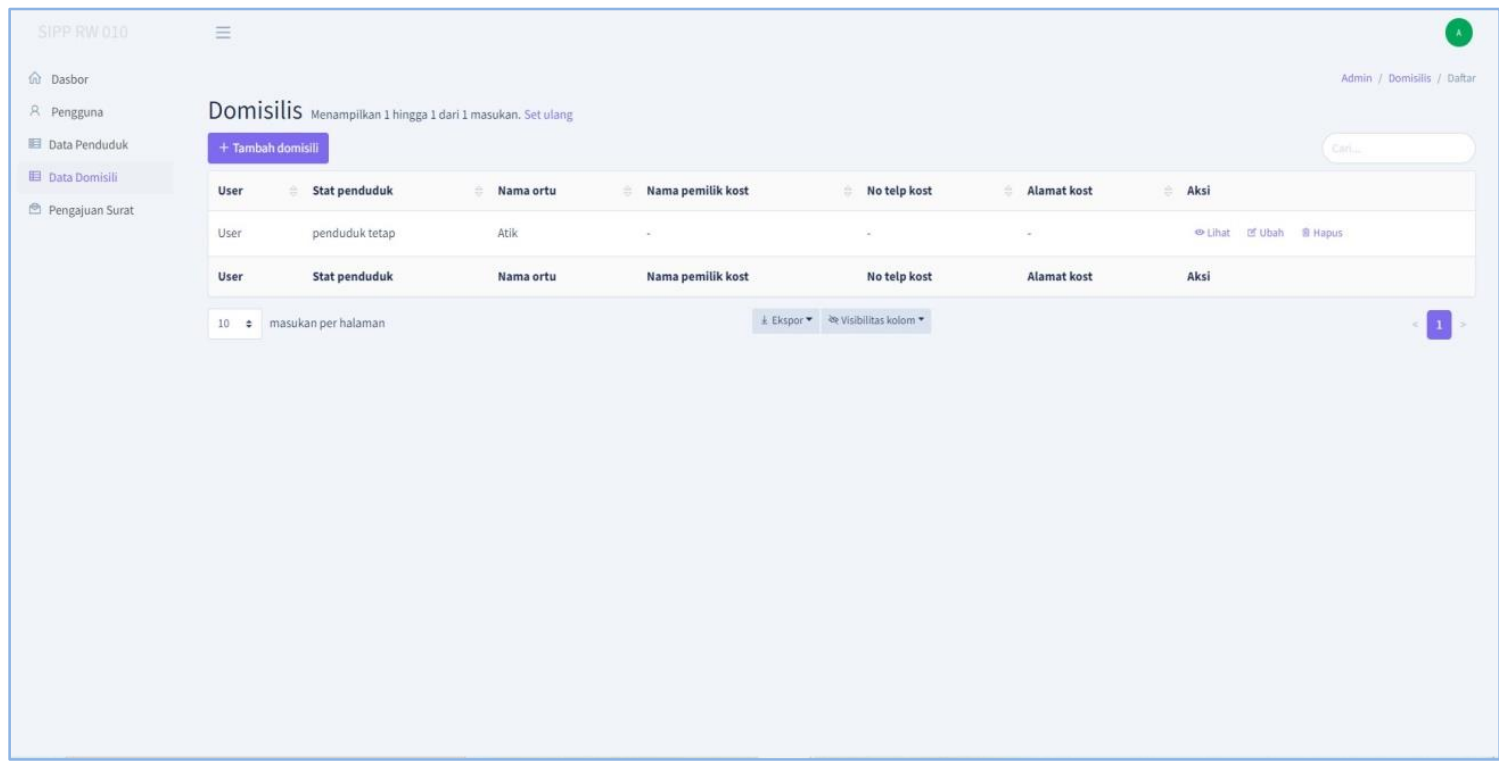

10

Gambar 17. Implementasi Halaman Data Status Domisili Penduduk

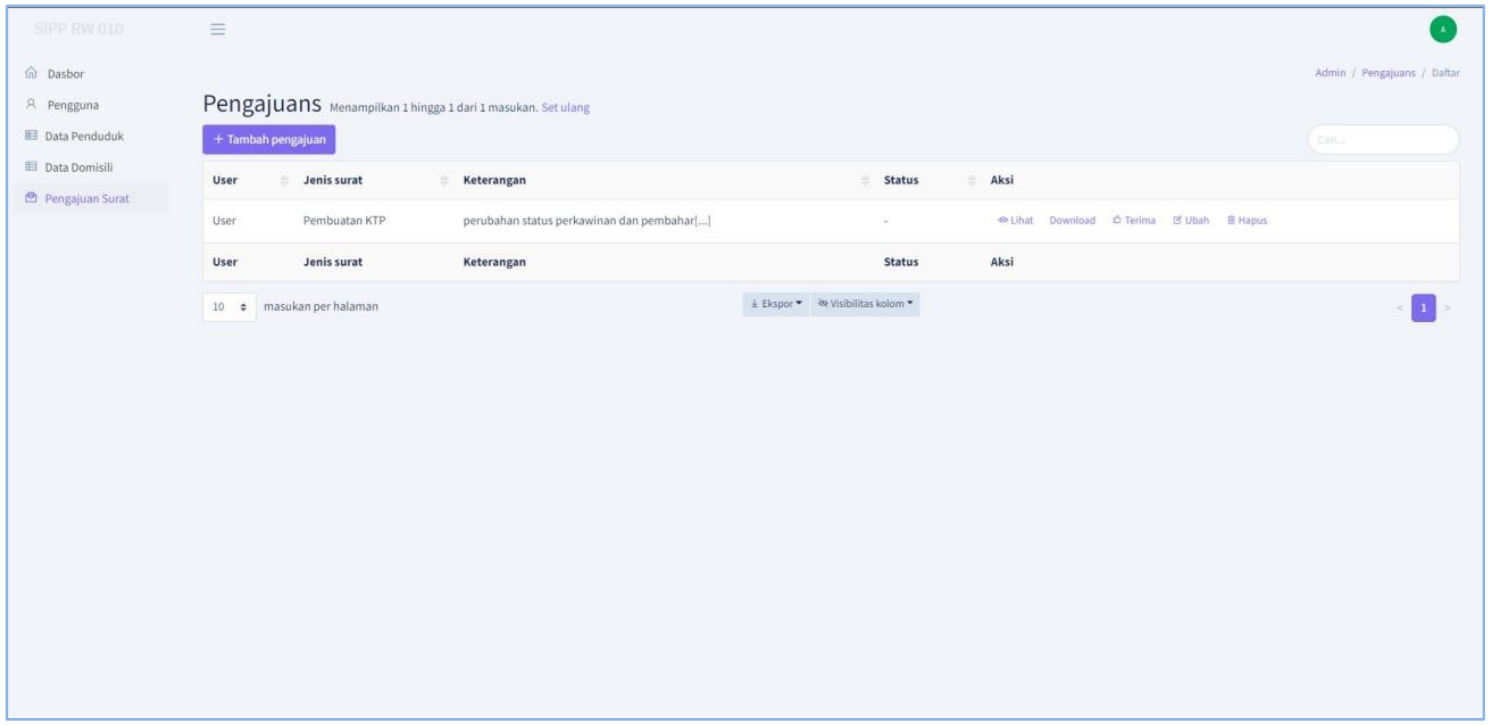

Gambar 18. Implementasi Halaman Daftar Pengajuan Surat 
DOI: $10.52362 / j m i j a y a k a r t a . v 1 i 1.414$

11. Hasil Surat

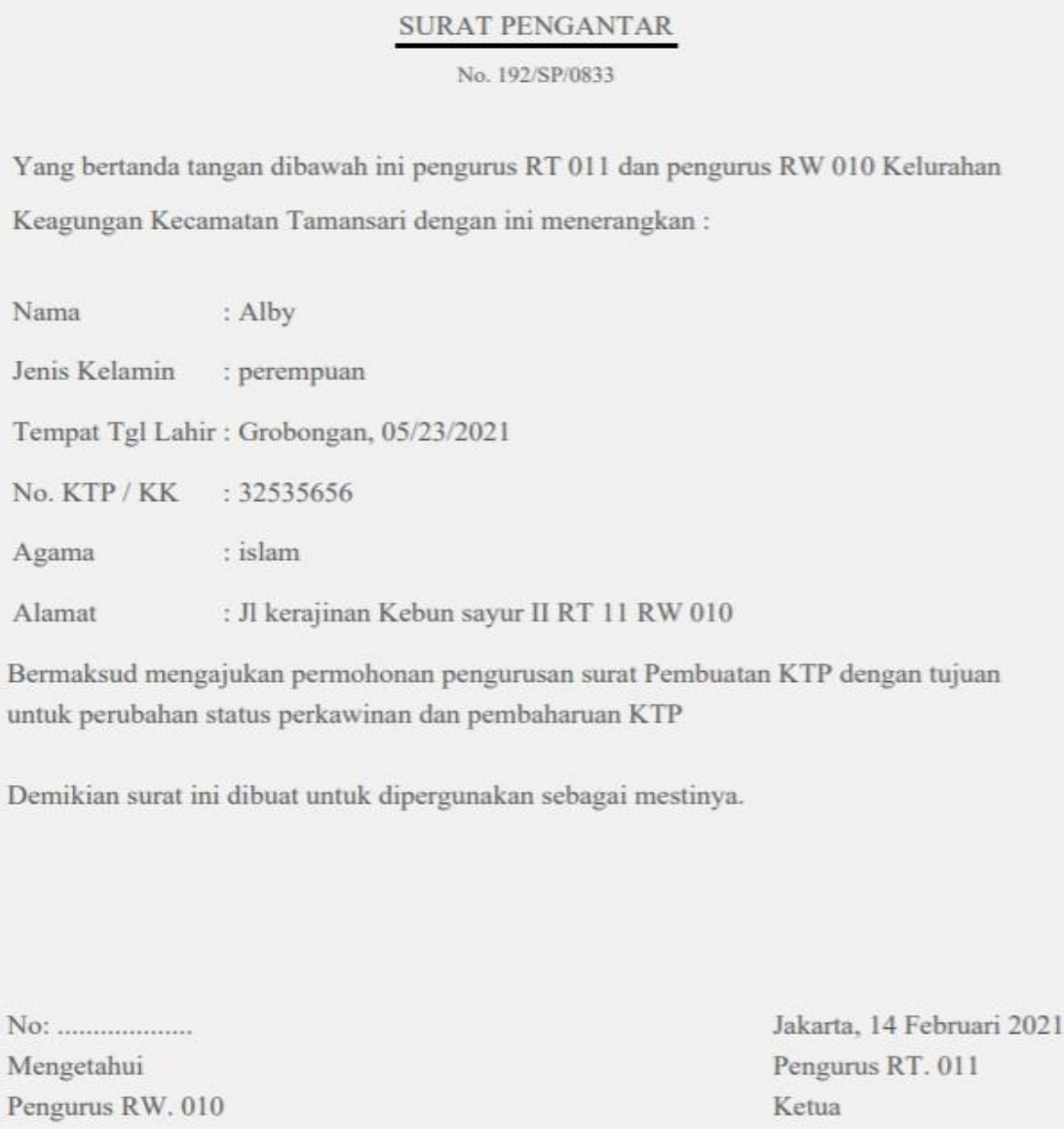

Gambar 19. Implementasi Surat Pengantar

\section{KESIMPULAN}

Berdasarkan kesimpulan yang dapat diambil dari keseluruhan penelitian ini :

1. Hasil perancangan sistem informasi pelayanan penduduk berbasis web model UML dengan alur aliran sistem use case diagram, sequence diagram dan class diagram.

2. Dengan sistem informasi pelayanan penduduk berbasis web ini maka proses pelayanan antara penduduk dan pengurus menjadi lebih akurat, efektif dan efisien, terutama dalam pendataan penduduk serta pembuatan surat pengantar. Penduduk tidak lagi harus mendatangi pihak pengurus atau bahkan menunggu pihak pengurus ada ditempat untuk meminta surat pengantar. Pengurus pun tidak harus lagi mendatangi rumah - rumah penduduk maupun mencatatnya satu - persatu untuk mendata penduduknya.

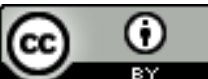

Ciptaan disebarluaskan di bawah Lisensi Creative Commons Atribusi 4.0 Internasional. http://journal.stmikjayakarta.ac.id/index.php/JMIJayakarta 
DOI: $10.52362 /$ jmijayakarta.v1i1.414

3. Sistem memudahkan pengurus RW 010 dalam menjalankan tugasnya dalam mengelola data serta membuatkan surat pengantar. Karena data yang ada dalam proses penyimpanan dengan database dan tersedia menu untuk mengajukan pembuatan surat.

\section{REFERENASI}

[1] Peraturan Gubernur (PERGUB) Nomor 1/SR.168/2014 tentang Pedoman Rukun Tetangga dan Rukun Warga

[2] Bitar. (2021, Januari 14). Retrieved Januari 20, 2021, from Pengertian Sistem - Karakteristik, Elemen, Jenis, Klasifikasi, Para Ahli: https://www.gurupendidikan.co.id/pengertian-sistem/

[3] Furqoni, M. (2014). STRATEGI MENINGKATKAN KUALITAS PELAYANAN PUBLIK DI KANTOR DINAS. Kualitas Pelayanan Publik Pada Pelayanan e-KTP, 1-12.

[4] Asmuruf, M. F., Rumate, V. A., \& Kawung, G. M. (2015). PENGARUH PENDAPATAN DAN JUMLAH PENDUDUKTERHADAP PENDAPATANASLI DAERAH ( PAD )DI KOTA SORONG. Jurnal BerkalaIlmiah Efisiensi, 727-737.

[5] Swara, G. Y., \& Pebriadi, Y. (2016). Rekayasa Perangkat Lunak Pemesanan Tiket Bioskop Berbasis Web. Jurnal TEKNOIF, 27-39.

[6] Sasmito, G. W. (2017). Penerapan Metode Waterfall pada Desain Sistem Informasi Geografis Industri Kabupaten Tegal. Jurnal Informatika: Jurnal Pengembangan IT(JPIT), 6 - 12. 